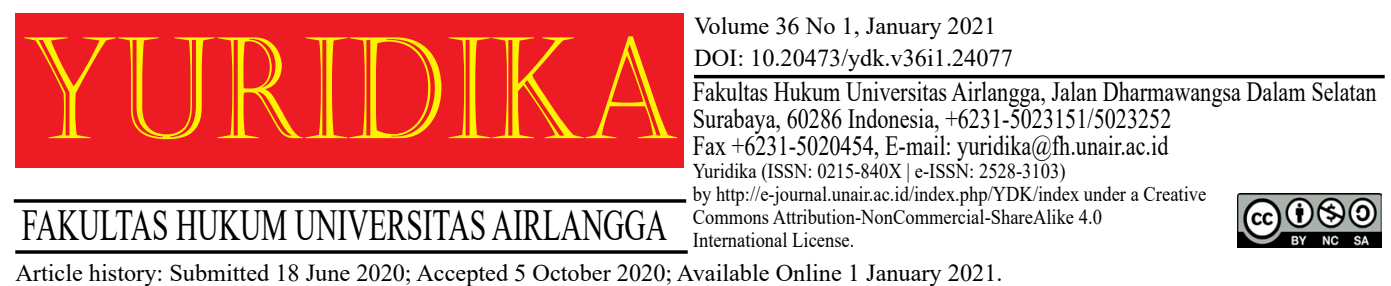

\title{
The Tensions On The Protection Of Local-Traditional Indonesian Batik
}

\author{
Ria Setyawati, Mas Rahmah, Rahmi Jened, \\ Nurul Barizah and Agung Sujatmiko \\ Ria.setyawati@fh.unair.ac.id \\ Universitas Airlangga
}

\begin{abstract}
Batik artwork has been known for hundreds of years and has become part of the culture of Indonesian society. Some batik motifs in Indonesia have philosophical values and are part of traditional traditional ceremony activities. Along with the times, the creativity of batik artists has become varied even though ancient traditional motifs are still mass produced and used as inspiration. This research examines the legal protection for traditional batik in order to avoid the abuse of rights by certain parties who merely exploit it in order to benefit from the existence of traditional batik works. The formulation of the problem that will be examined in this research is whether traditional batik gets legal protection under the copyright regime in Indonesia? Are there any legal safeguards at the international level for traditional Indonesian batik works? In answering this problem formulation will use a conceptual approach and a statutory approach. This research is a legal research that will examine existing legal concepts and related legal rules in solving legal problems related to the protection of traditional batik.
\end{abstract}

Keywords: Batik Protection; Copyright; Volklore.

\section{Introduction}

Indonesian copyright regime is regulated under the Law of the Republic of Indonesia Number 28 year 2014 regarding Copyright (Law No. 28/2014). ${ }^{1}$ Pursuant to Considering a, Law No. $28 / 2014$, it is stated that Indonesia is a country with a wide range of diversity in ethnics/tribes and culture as well as wealth in the field of arts and literatures, and thus needs the protection of Copyright for the intellectual property originating from the diversity. ${ }^{2}$ Meanwhile, the development in the field of

1 Law Number 28 Year 2014 Concerning Copyright (The Republic of Indonesia State Gazette Year 2014 Number 266, Annotation 5599).

2 ibid.Considering: a. 
trade, industry, and investment has grown so rapidly that it required legal certainty on the protection for Authors and Owners of Related Rights by considering the interests of the public in general. ${ }^{3}$ An example of the traditional art that discussed here is batik. Batik is one of the artistic works from Indonesia especially from Java.

Batik is decorated fabric from Indonesia. A traditional batik uses special technique called as wax-resist dyeing. Traditional wax-resist dying is started by handdyeing fabrics using wax to cover parts of the pattern with a tool known as canting, dyeing the uncovered fabric with colors, and dissolving the wax in boiling water. There are thousands motives of Batik in Indonesia. ${ }^{4}$ Many regions or even in many cities have their own batik with their distinction characteristics. Batik from East Java, for example, has different characteristic of motive than that of Central Java. Batik from East Java has brighter and more colorful motive then those from Central Java. Furthermore, batik from different cities in East Java, namely Mojokerto and Madura, have different characteristics as well. Indonesian Government sees this variety of batik as a national treasure that should be protected under copyright regime. ${ }^{5}$

Through Indonesian Government point of view, the protection of batik is necessary for two reasons; first, it is for protection of utilization/exploitation and the second is for preservation of culture, knowledge, and resources of themselves. ${ }^{6}$ Under Law no.28/2014, some batik motives have been registered as folklore from a Region. Pekalongan ${ }^{7}$ Regional Government has been registering 96 batik to Directorate General of Intellectual Property Indonesia (DGIPR). ${ }^{8}$ Ten out of 96 Pekalongan Batik are certified, and Pekalongan Regional Government is the copyright owner for those creation. ${ }^{9}$ Through the registration, Indonesian

3 ibid.Considering: c.

4 Indonesian Batiks, <www.indobatiks.com>.

5 More detail in the second chapter.

6 Ansori Sinungan, 'Intellectual Property, TRIPs and Preserving Cultural Heritage and the Environment: Indonesian Experience'<www.unescap.org>.[3]; More detail about the reasons in the second chapter.

7 Pekalongan is a city in Central Java.

8 Dindagkop Pekalongan, 'Motif Batik Terdaftar Di Ditjen HKI' < perindagkop.pekalongan kota.go.id $>$.

9 ibid. 
Government hopes that the protection for Indonesian folklore is regulated under the law. In this matter, some problems arise regarding the protection of batik as Indonesian folklore under copyright regime. It remains a debate among scholars whether folklore as native culture should be owned by individuals or communal. ${ }^{10}$ Meanwhile, World Intellectual Property Organization (WIPO), these days, ${ }^{11}$ tries hard to formulate provisions regarding the traditional knowledge and folklore. ${ }^{12}$ The main purpose of this study is to analyze the best way of the protection of Indonesian batik (as a folklore) under copyright regime. The term "the best way" here does not only refer to the protection for the authors as individuals and the communal, but also for protection of human rights.

Based on the aforementioned purposes, this study is developed to answer some research questions as follows: (1) How does Indonesian Government protect batik as Indonesian native culture? (2) How is the protection of folklore in international level? (3) Who owns the author's right and copyright for traditional batik in Indonesia? This study will be structured in five chapters. The first chapter is the introduction and the next chapters will be structured as follows: The second chapter discusses two issues. The first issue is the existence of batik as one of the Indonesian folklore. This session investigates the definition of folklore and how batik becomes one of Indonesian folklores. The second issue is the protection of folklore in Indonesian National Law. There are some regulations in Indonesian National Law dedicated to protect Indonesian native cultures, namely, Copyright law No. 28/2014, Cultural Heritage Law No. 5/1992, Government Regulation No. 10/1993 for implementation of Law no. 5/1992, Presidential Decree No. 84/1999 for Utilization of Art and Culture, Government Regulation No. 78/2007 concerning ratification of convention for safeguarding of the Intangible Cultural Heritage. Through these regulations, the study investigates the current law applicable in Indonesia regarding traditional folklore.

\footnotetext{
${ }^{10}$ Michael F. Brown Kristen Carpenter, 'In Defense of Property' [2010] Journal Cultural Property.

11 Year of 2012.

12 World Intellectual Property, 'The Protection of Traditional Knowledge: Draft Articles' $<$ www.wipo.int $>$.
} 
The third chapter discusses the protection of folklore in international level. First issue is the tensions on the Protection of Folklore in the International Level. This subchapter discusses different views of folklore protection between indigenous cultures and Western law system. Here, the difference between the nature of indigenous peoples' customary law and the nature of intellectual property law is also discussed. The difficulties in folklore protection in international level are concerned in this discussion. Second issue is the Protection of Folklore under Copyright Regime in International Level. It is started with folklore in UN Declaration of Indigenous People. Further discussion is about the protection of folklore since the Berne Convention until the latest revised version of draft Articles of the 22nd WIPO Intergovernmental Committee (ICG) on Intellectual Property and GRTKF.

The fourth chapter discusses two issues. The first issue deals with Author right and copyright for traditional Indonesia Batik. After brief explanation on the previous chapter, this session investigates who owns batik as one of Indonesian native cultures. The second issue deals with the extended creation of traditional batik. This session discusses the possibility for individuals to own batik as the extended version of the traditional batik.

The fifth chapter is the conclusion of all chapters and provides answers to the research questions. The method of writing of this thesis is normative method. The normative method here is based on research on literature. This research is conducted by analyzing the legal documents and other relevant sources.

The legal document consists of the related treaties, Regulations, and other legal sources which are relevant to the topic in this thesis. The related international Treaties include TRIPs, Berne Convention 1986, and WIPO Copyright Treaty. National Regulations that contribute to the protection of folklore are Copyright law No. 28/2014, Cultural Heritage Law No. 5/1992, Government Regulation No. 10/1993 for implementation of Law no. 5/1992, Presidential Decree No. 84/1999 for Utilization of Art and Culture, and Government Regulation No. 78/2007 concerning on the ratification of convention for safeguarding of the Intangible Cultural Heritage. Other relevant sources consist of explanations and opinion in books, academic journals, articles, seminars, and dictionary. 


\section{Batik as Indonesian Cultural Heritage: The Existence of Batik as Indonesian Folklore}

For years folklorists try to make a comprehensive definition of folklore. The definition of folklore becomes an essential matter when there are the demands of some countries to protect their folklore and to put it not only into their national law but also into international law. Many discussions in national or international forum were held to provide the definition of folklore. In early $1960 \mathrm{~s}$, the term 'folk' for contemporary American folklorists refers to any group of people whatsoever who share at least one common factor. ${ }^{13}$ The linking factor could be common occupation, common language, or common religion. The idea of the term of folk is also known as the concept of folk. The concept of folk becomes more rigid along the development of the definition of folklore. For folkloric art, the group of people should have the same reference, share similar values, believes and background knowledge, and also have the same system of codes and signs for social interaction. ${ }^{14}$ The important thing is that the group will have some traditions which are called as their own. At this point, the group of people have unique characteristic different from the other groups.

Further, the definition of folklore, on one hand, is constructed on the basis of sets of relations between the social context, the time depth, and the medium of transmission. On the other hand, it is constructed based on the conception of folklore as a body of knowledge, mode of thought, and kind of art. ${ }^{15}$ In 1982, United Nations Educational, Scientific and Cultural Organization (UNESCO) tried to formulate the definition of folklore. Based on UNESCO recommendation on the safeguarding of traditional culture and folklore, "folklore (or traditional and popular culture) is the totality of tradition-based creations of a cultural community, expressed by a group or individuals and recognized as reflecting the expectations of a community in so far as they reflect its cultural and social identity; its standards and values are

\footnotetext{
${ }^{13}$ Alan Dundes, Analytic Essays in Folklore (Mouton Publishers 1979).[7].

${ }^{14}$ Dan Ben-Amos, 'Toward a Definition of Folklore' (2006) <www.jstore.org/journals $>$.[12].

15 ibid.[5].
} 
transmitted orally, by imitation or by other means. Its forms are among others: language, literature, music, dance, games, mythology, rituals, customs, handicrafts, architecture and other arts". ${ }^{16}$

UNESCO - WIPO Model Provisions for National Laws on the Protection of Expressions of Folklore against Illicit Exploitation and Other Prejudicial Actions of 1982 at the Section 2 mentions the expressions of folklore. Expressions of folklore mean productions consisting of characteristic elements of the traditional artistic heritage developed and maintained by a community of [name of country] or by individuals reflecting the traditional artistic expectations of such community. Furthermore, in the same section of this model provisions, expressions of folklore fall into two categories, intangible and tangible. Intangible expressions of folklore include verbal expressions (folk tales, folk poetry and riddles), musical expressions (folk songs and instrumental music), expressions by actions (folk dances, plays and artistic forms or rituals). Tangible expressions of folklore include productions of folk art (drawings, paintings, carvings, sculptures, pottery, terracotta, mosaic, woodwork, metal-ware, jewelry, basket weaving, needlework, textiles, carpets, costumes), musical instruments, and architectural forms.

Based on the definitions of folklore from many resources above, there are some basic elements to categorize the subject of folklore, they are:

1. Creations of a traditional artistic works;

2. In certain community or group of people or region;

3. Inherited from generation to generation;

4. Constitute of the cultural heritage of the community or the group of people or the region.

With regard to the definition of folklore, Batik, could meet the basic elements of folklore stated above. To further investigate Batik as Indonesian folklore, it is important to know the history of Batik in Indonesia. Over 2000 years, evidence of early examples of Batik has been found in the Far East, Middle East, Central

\footnotetext{
${ }^{16}$ Intergovernmental Committee on Intellectual Property and Genetic Resources Traditional Knowledge and Folklore, 'Traditional Knowledge-Operational Terms and Definitions' (Third Session, Geneva, 2002) <www.wipo.int>.[11].
} 
Asia and India. ${ }^{17}$ It is more likely that the craft spread from Asia to the islands of the Malay Archipelago and west to the Middle East through the caravan route. Batik has reached its greatest peak of complement in Indonesia, particularly in the Java and Bali. ${ }^{18}$ Since 932 A.D, Batik, has been known in Java. The traditional skills were well developed over hundreds of years in Central Java, particularly in Mataram, Yogyakarta and Solo, when those areas were still under the patronage of Sultans (kings) and his court. The designs of Batik were copied, and in some cases it could only be used by certain people or in certain occasions. For example, one of the Batik motives, Batik Parang Rusak from Yogyakarta, ${ }^{19}$ was used by the soldiers as their clothes after the war to show to the King that they won. ${ }^{20}$ The royal families had their own proscribed designs, to name Batik Parang Klitik. ${ }^{21}$ For long decades, Indonesian Batik permeates the lives of Indonesians from their beginning to the end: infants are carried in Batik slings decorated with symbols of luck, and the dead are shrouded in funerary Batik. Clothes with everyday designs are worn regularly in business and academic settings, while special varieties are incorporated into celebrations of marriage and pregnancy and into puppet theatre and other art performances. The garments even play the central role in certain rituals, such as ceremonial casting of royal Batik into volcano. ${ }^{22}$

Batik was spread in all over areas in Indonesia. Every region or every communal has their own characteristics for Batik motives. Furthermore, every traditional Batik motive has philosophical meaning. The craft of Batik is intertwined with the cultural identity of Indonesian people, through the symbolic meanings of its colors and designs, expressing their creativity and spirituality. ${ }^{23}$ The knowledge for the traditional motives and the making process are often handed down within families across generations.

\footnotetext{
${ }^{17}$ University of Northern Colorado, 'History of Indonesian Batik' <www.arts.unco.edu >.[1].

18 ibid.

${ }^{19}$ Berliana N. Rohima, 'Parang Rusak, One of Batik Motif' (2012)<lianrohima.wordpress.com>.

20 ibid.

21 ibid.

${ }^{22}$ UNESCO, 'Indonesian Batik' (2009) <www.unesco.org>.

23 ibid.
} 
The development of traditional Batik is not static. The development of Batik is not only in the motives but also in the process and the materials to create it. Batik motives have wide diversity of patterns reflecting a variety of influences, ranging from Arabic calligraphy, European bouquets, Chinese phoenixes to Japanese cherry blossoms and Indian or Persian Peacock. ${ }^{24}$ Until the day, there are thousands Batik motives in Indonesia crated by Batik artists.

The making process of Batik has developed. Before 1800s, traditional Batik used hand made wax-resist dying. To make it easier and faster, the cloth is stretched on to long tables, and a cap or copper stamping tool is used. Today, Batik reaches its mass production by manufactures. Based on the information above, Indonesian Batik has fulfilled the basic elements as folklore of Indonesia:

1. Batik as a creation of traditional artistic works

For example, Parang Rusak or defective big knife is a traditional Batik pattern from Yogyakarta. It is visualized on cotton or silk as many defective big knife, a traditional weapon for soldiers, with diagonally format in a perfect precision. Usually it is colored in brown and white. Thereby, Batik Parang Rusak is a creation of a traditional artistic works.

2. Indonesian Batik developed in certain community or group of people or region As already mentioned above, in a certain area, for example in Yogyakarta, there are many patterns of Batik that have been made and have unique characteristic of the local community. It is inherited from generation to generation, and constitutes the cultural heritage of the community or the group of people or the region

3. The long history of Indonesian Batik has proved that it passed from one to another generation. The use of Batik in almost every day lives of Indonesians, even for traditional ceremonial, for example at wedding ceremony, proves that Batik constitutes a cultural heritage of Indonesia.

The aforementioned basic elements of folklore can be used as a basis to categorize Batik as an Indonesian folklore. Furthermore, in 2009, UNESCO stated 
acknowledgement of Indonesian Batik as one of Indonesian intangible cultural heritages. ${ }^{25}$ The acknowledgement by UNESCO means that the world finally recognizes and acknowledges Batik as an Indonesian heritage. ${ }^{26}$ When UNESCO adds Indonesian Batik into a global list of intangible cultural heritage on 1st October 2009, Indonesia can at least officially proclaim its cultural belonging during the along-standing dispute between Indonesia and Malaysia over the origins of Batik. ${ }^{27}$

As intangible cultural heritage, there are several things to concern. Pursuant to Article 2 in the Convention of Safeguarding of the Intangible Cultural Heritage: The General Conference of the UNESCO ${ }^{28}$ the intangible cultural heritage means the practices, representations, expressions, knowledge, skills - as well as the instruments, objects, artifacts and cultural spaces associated. In this point of view, the acknowledgement of Indonesian Batik by UNESCO is only as far as the knowledge of the process to create Indonesian Batik by using the traditional tools and materials, the expressions of the meaning of traditional Batik and also as a part of tradition in Indonesian life. Among thousands motives of Batik in Indonesia, the official web site of UNESCO does not specifically mention which pattern belongs to Indonesian cultural heritage.

In copyright regime, the object of the protected 'work' is a creation of the human mind. ${ }^{29} \mathrm{~A}$ creation is protected by copyright if it constitutes an original work that is recorded in some permanent forms. ${ }^{30}$ In this point of view, the motives of Batik could be the object that are protected under copyright regime. The idea to protect folklore in Indonesia is based on the belief that sustainability of cultural national heritage is important for understanding and development of history, science and

\footnotetext{
25 ibid.

${ }^{26}$ Peter Gelling, 'Score One for Indonesia in the War Over Batik' (2009) <www.nytimes.com>.

${ }^{27}$ Tasa Nugraha Barley, 'Indonesia and Malaysia Battle Over Batik' (2009) <www. thejakartaglobe.com>.

${ }^{28}$ The General Conference of UNESCO, 'Convention for the Safeguarding of the Intangible Cultural Heritage' (2003).

${ }^{29}$ Andreas Rahmatian, Copyright and Creativity the Making of Property Rights in Creative Works (Edward Elgar 2011). [14].

${ }^{30}$ ibid.
} 
culture, and as national identity, also for national interest. ${ }^{31}$ Protection of folklore prevents monopolization and commercialization, and/or other undermining acts of national folklore by person(s) and/or entities. In Indonesia, folklore involves both the expressions of traditional and popular culture and the works based on these expressions. Later, the works are not only protected by copyright but also outside copyright regime.

Law of Republic of Indonesia Number 5 year 1992 about cultural heritage (Law No. 5/1992) is one of regulations about the protection of cultural heritage outside copyright regime. The aim of this law is to manage the ownership, discovery, searching, protection, maintenance, utilization and control of cultural national heritage. In practice, Law No.5/1992 has effectively had its function after the Government Regulation Number 10 Year 1993 regarding the implementation of Law No. 5/1992.

Pursuant to Article 1 Law No. 5/1992, cultural heritage is an object made by person, individual or communal, aged at least 50 years old, and it has important value for history, science, and culture. All of the cultural heritage are owned and controlled by the state. ${ }^{32}$ According to Article 6 (a) in this regulation, only certain cultural heritage has possibility owned by individual with certain condition; the cultural heritage is owned for generations of an individual. Furthermore, in Article 7, it is mentioned that only the State who has the right to transfer the ownership of the cultural heritage. Furthermore, without the state permission, a cultural heritage could not: bring out to the Indonesian territory, move the object of the cultural heritage from one area to another area, move in apart or entirely except in emergencies, separate it from its unity, change the shape and/or the color, sale it or do an economic interest using the object of cultural heritage. In the Law no. 5/1992 point of view, traditional Batik could be owned by individual (or communal), and only the state who has the right to transfer the ownership of Batik. In this matter, even though it is owned by individual or communal, the state still has its control in certain conditions.

${ }^{31}$ Consideration : Law Number 28 Year 2014 Concerning Copyright (The Republic of Indonesia State Gazette Year 2014 Number 266, Annotation 5599) (n 1).

32 Article 4 (1), ibid. 


\section{Protecting Folklore under Copyright Law in Indonesia}

Under copyright regime, folklore is protected in Law No. 28/2014. This Law came into force on October 16, 2014. ${ }^{33}$ After the effectiveness date, Law Number 19 year 2002 regarding copyright is declared no longer valid..$^{34}$ According to Indonesian copyright law, ${ }^{35}$ folklore or expressions of traditional culture includes either or a combination of the expression form as following:

a. textual verbal, both spoken and written, that is in the form of prose and poetry, in various themes and the contents of the message, which can be in the form of literature or informative narrative;

b. music, including, among other things, vocal, instrumental, or the combination;

c. movement, including dance;

d. theater, including puppet shows and folk plays;

e. fine arts, both in two and three dimensions made of various kinds of materials such as leather, wood, bamboo, metal, stone, ceramic, paper, textile, and others or a combination thereof; and

f. traditional ceremonies.

To analyze folklore, it is important to begin with the meaning of copyright in Indonesia copyright law. The meaning of copyright in Indonesia copyright law is stated in Article 1 (1) Law No. 28/2014, Copyright means an exclusive right of an author that arises automatically based on the declarative principle after a work is manifested in a tangible form without without decreasing the limits according to the prevailing laws and regulations. In this Article, there are four elements: exclusive right, author, publication/declaration and reproduction, and work.

Exclusive right means the basic right conferred on the Author as the first owner of a work. The Author may distribute the right to another person. The author or the recipient of the right has an exclusive right to control and/or restrict the acts of copying. Author means a person or several persons who jointly formulate an inspiration on particular work to produce, based on the intellectual ability, imagination, dexterity, skill or expertise manifested in a distinctive form and is of

\footnotetext{
${ }^{33}$ As stated in Article 126 Law Number 28 Year 2014 Concerning Copyright (The Republic of Indonesia State Gazette Year 2014 Number 266, Annotation 5599) (n 1). This Law shall take effect right after the date of its ratified....".

${ }^{34}$ Considerate on ibid.

35 Explanation of Article 38 (1) ibid.
} 
a personal nature ${ }^{36}$ The recipient of the right refers to copyright holder. Copyright holder is any person who receives or subsequently receives the right from the author or the aforesaid person as the owner of the copyright. ${ }^{37}$

Publication/declaration means the reading, broadcasting, exhibition, sale, distribution or dissemination of a Work, by utilizing whatever means including the Internet, or by any manner so that such work is capable of being read, heard or seen by any other person. ${ }^{38}$ Reproduction means to increase the number of a work, either as a whole or its substantial parts using either the same or different material, including the changing of the form or mode of a work permanently or temporarily. ${ }^{39}$ Work here means any result of works of an author, which shows originality in the field of science, arts and literature that is produced based on inspiration, ability, thought, imagination, dexterity, skill, or expertise that is expressed in a tangible form. ${ }^{40}$ Furthermore, in Article 1 (1) Law juncto Article 9 (1) Law No. 28/2014, the state grants an automatic protection after the creation of the work for an author or a copyright holder to publish or reproduce his/her work. For deeper investigation on Batik in the Indonesian copyright regime, first of all, it is important to know Indonesian copyright law. The three important question words about copyright are what, who, and how. ${ }^{41}$ First, what are the objects of copyright in Indonesian copyright law? Copyright domain in Indonesia is works in the field of science, arts, and literature. ${ }^{42}$ Furthermore, there is non-exhaustion list of works which are protected under Indonesian copyright law. Pursuant to Article 40 Law No. 28/2014, works protected under copyright includes:

a. books, pamphlets, appearance of published papers, and all other written works;

b. lectures, lectures, speeches, and other similar works;

\footnotetext{
${ }^{36}$ Article 1 (2) ibid.

37 Article 1 (4) ibid.

${ }^{38}$ Article 1 (11) ibid.

39 Article 1 (12) ibid.

40 Article 1 (3) ibid.

${ }^{41}$ Melchers, Dorothé, International and Comparative Copyright Law: Introduction to Copyright (Radboud Universiteit 2011).[2].

42 Article 40 (1) Law Number 28 Year 2014 Concerning Copyright (The Republic of Indonesia State Gazette Year 2014 Number 266, Annotation 5599) (n 1). “... in the field of science, arts and literature".
} 
c. teaching aids made for the benefit of education and science;

d. songs and/or music with or without subtitles;

e. drama, musical drama, dance, choreography, puppetry, and pantomime;

f. fine arts in all forms such as paintings, drawings, carvings, calligraphy, sculpture, sculpture or collage;

g. work of applied art;

h. architectural works;

i. map;

j. batik artwork or other motif art;

k. photographic works;

1. portrait;

m. cinematograph works;

n. translations, interpretations, adaptations, anthologies, databases, adaptations, arrangements, modifications and other works resulting from the transformation;

o. translation, adaptation, arrangement, transformation, or modification of traditional cultural expressions;

p. compilation of works or data, either in a format that can be read by a computer program or other media;

q. compilation of traditional cultural expressions as long as the compilation is original;

r. video games; and

s. Computer program.

Meanwhile in Article 41 Law No. 28/2014, it is stated that there shall be no copyright to:

a. works that have not been translated into tangible forms;

b. any idea, procedure, system, method, concept, principle, finding or data even though it has been disclosed, stated, described, explained, or combined in a work; and

c. tools, objects or products that are created solely to solve technical problems or whose form is intended only for functional purposes.

Second, who are the subjects of copyright protection in Indonesian copyright law? There are two subjects in Indonesian copyright law, author and copyright holder. Pursuant to Article 1 (2) Law no. 28/2014, Author means a person or several persons who jointly formulate an inspiration on particular work to produce, based on the intellectual ability, imagination, dexterity, skill or expertise manifested in a distinctive form and is of a personal nature. While a right holder, according to Article 1 (4) Law No. 28/2014, means any person 
who receives or subsequently receives the right from the author or the aforesaid person as the owner of the copyright.

Third, how is the copyright protected under Indonesian copyright law? In Indonesian copyright law, there are protections for exploitation rights and moral rights. The basic idea of exploitation rights is copyright that involves the creative industries with considerable implications for incentives to the authors and copyright holder. ${ }^{43}$ The exploitation rights are valid for the life of the longest surviving author and continue until 70 (seventy) years after the death of the said longest surviving author. ${ }^{44}$ The author may license, assign or sell these rights outright or in part or transfer them to another person. Such transaction is made through contracts. In Indonesian copyright law, more details about license are stated in Article 80-86 Law No. 28/2014.

The author's moral right in the work may not be sold or transferred. ${ }^{45}$ The basic idea of moral right is that a State grants some kind of payment forms more than just a monetary income to author, but also symbolizes recognition and status. ${ }^{46}$ In Indonesian copyright law, moral right is stated in Article 5-7 Law no. 28/2014. Pursuant to article 5 (1), an author or his/her heir should be entitled to require the copyright holder to attach the name of the author on his work. Furthermore, in Article 98 (1), even though a copyright has been transferred to another party, it is forbidden to make changes of the work (including the changing of the title and subtitle to a work inclusion and the changing of the name or pseudonym of the

\footnotetext{
${ }^{43}$ Ruth Towse, Creativity, Incentive and Reward: An Economic Analysis of Copyright and Culture in the Information Age (Edward Elgar 2001).[7].

44 Article 58 (1) Law Number 28 Year 2014 Concerning Copyright (The Republic of Indonesia State Gazette Year 2014 Number 266, Annotation 5599) (n 1). Exception for the term of protection of the exploitation right is in Article 59 Law No. 28/2014 (for photographic works; portrait; cinematographic works; video games; computer program; compilation of written works; translations, interpretations, adaptations, anthologies, databases, areangements, modifications and other works resulting from the transformation; translation, adaptation, arrangement, transformation or modification of traditional cultural expressions; compilation of Works or data, either in a format that can be read by a computer program or other media; and compilation of traditional cultural expressions, valid for 50 years as of the first publication), and in Article 60 Law No. 28/2014 (folklore is no limit of time).

${ }^{45}$ Ruth Towse (n 43).[9].

46 ibid.[8].
} 
author), without the consent of the author or his/her heir if the author has been deceased. The copyright of a work should remain in the hands of the author as long as the entire copyright is not transferred to the purchaser of the work. ${ }^{47}$ There is no time limit for the term of protection of moral right. ${ }^{48}$ Copyright law does not protect ideas, only the expression of the work in the fixed form (the fixation). The protection of copyright of the author as the creator of the work is granted by Indonesian Government automatically after the creation of the fixation of the work. ${ }^{49}$ In this matter, registration for a work should not be an obligation to obtain a copyright.$^{50}$ Registration ${ }^{51}$ here means an administrative way to register and record a work to the Ministry. ${ }^{52}$ The registration system for copyright under the Law No. $28 / 2014$ is only for declaration of a work. Even though there is no obligation to register, authors should register their works to facilitate proof in court if there is a dispute over the works.

After the discussion about the global principle of Indonesia copyright regime to answer the three question words (who, why, how), the following issue to discuss is, batik as folklore in Indonesian copyright law. To protect Indonesian Batik, Indonesian Government attempts to register traditional Indonesian Batik at DGIPR. There are many traditional Batik registered as copyright by local Indonesian Governments at DGIPR, for example, ten Batik motives from Pekalongan, ${ }^{53} 84$ Batik motives from Jambi, ${ }^{54}$ and 219 Batik motives from Semarang. ${ }^{55}$ In Article 38 Law No. 28/2014, it is stated that the State holds the copyright for folklores or expressions of traditional culture. Pursuant to Article 60 (1) Law No. 28/2014, the

\footnotetext{
47 Article 5 (2) Law Number 28 Year 2014 Concerning Copyright (The Republic of Indonesia State Gazette Year 2014 Number 266, Annotation 5599) (n 1).

${ }^{48}$ Article 57 (1) ibid.

${ }^{49}$ Article 1 (1) ibid.

${ }^{50}$ Article 64 (2) ibid.

${ }^{51}$ More detail about registration of works is stated in Article 64-79 ibid.

52 Article 64 (1) ibid.

${ }_{53}$ Dindagkop Pekalongan (n 8).

${ }^{54}$ Suhikmah, Upaya Pemerintah Daerah Provinsi Jambi Dalam Rangka Perlindungan Hukum Terhadap Ciptaan Motif Batik Yang Belum Terdaftar (Universitas Diponegoro 2008).[75-79].

${ }_{55}$ Bisnis UKM, 'Batik Semarang 16 Kini Sukses Menembus Batas (bisnisukm 2012)' $<$ https://bisnisukm.com/batik-semarang-16-kini-sukses-menembus-batas.html $>$.
} 
copyright for folklore held or exercised by the State is valid without time limit. This is the case for Indonesian (local) Government of which copyright for Batik is not limited into a particular time frame.

Indonesian Government owns the copyright for some Batik motives which are registered as Indonesian folklore. Throughout history, Batik has been used for various products: industrial, spiritual, ethical, artistic, religious, and so on. As the copyright holder, Indonesian Government has the right to publish or reproduce Batik motives, and also to prevent monopolization and commercialization by others without permission.

Pursuant to Article 39 (1) Law No. 28/2014, the Indonesian Government (or the institution related to this matter) has the rights to publish or to reproduce Batik as an Indonesian Folklore. In other words, Batik is owned by the state. In Article 10 (4) Law No. 19/2002, further provision regarding copyright that are held by the State, should be regulated by Government Regulation. Until today, the Government Regulation mentioned in the Article has not been compiled. Since the Government Regulation regarding folklore and national heritage does not exist, the protection of folklore in Indonesia still lacks legal certainty. In order to provide legal certainty for indigenous culture (including folklore), the Government Regulation regarding folklore and national heritage should recognize indigenous traditions (including customs, languages, beliefs) and collective character of communities; and should also provide specific guarantees for all the assets.

\section{The Protection of Folklore in International Leve: The Tensions on the Protection of Folklore in the International Level}

Folklore, particularly in developing countries, is a living, functional tradition, rather than a mere souvenir of the past. ${ }^{56}$ As a basis cultural identity, folklore is an

\footnotetext{
${ }^{56}$ Model Provisions for National Laws on the Protection of Expression of Folklore Against Illicit Exploitation and Other Prejudicial Actions, UNESCO-WIPO, 1985, Introductory Observations. [Para.1].
} 
important means of self expression of people and for social identity. ${ }^{57}$ The value of folklore could differ in the Western countries. ${ }^{58}$ In many Western countries, expression of folklore are being commercialized without due respect for the cultural and without concedes of the communities in which they originate. In other words, there is different urgency of folklore protection between developing and Western countries within their national law.

The conflict between Western intellectual property system and indigenous people is rooted in the basic different point of view. Western intellectual property system considers that folklore is part of the public domain. While the indigenous people want to respect their folklore or traditional cultural heritage, and insist to protect it as confirmed by their laws.

Lewinski notes the differences between Western law system and indigenous cultures in the table. ${ }^{59}$

\begin{tabular}{ll}
\hline Western law system & Indigenous cultures \\
\hline Predominantly individualistic & Community-driven owned \\
Based on writing, fixation, and legal security on the & $\begin{array}{l}\text { Passed on orally from generation to } \\
\text { basis of written law }\end{array}$ \\
generation, often for long period of time \\
$\begin{array}{ll}\text { The arts societies have primarily entertaining } \\
\text { function and represent economic factor }\end{array}$ & $\begin{array}{l}\text { Folklore conveys meaning for every aspect } \\
\text { of life of indigenous communities }\end{array}$ \\
\hline
\end{tabular}

These features of Western concept reflect that individual creation and individual ownership are captured as an exclusive right of copyright. While for indigenous peoples, the emphasis is more on a spiritual synthesis within the community than individual ownership. This value construct of a work represents a communal right, and it surpasses any economic advantages. In addition, copied expression of their folklore by indigenous people leads to the claim for authentic creation, and it is surpassed from generation to generation. ${ }^{60}$ Furthermore, on the basis of an exclusive right, a right to give consent, or a statutory remuneration right, sharing benefits by the exploitation of folklore should be protected. It is difficult to

\footnotetext{
57 ibid.

${ }^{58}$ Silke von Lewiski, International Copyright Law and Policy (Oxford 2008).[527].

${ }^{59}$ ibid.[528].

${ }^{60}$ ibid.[529].
} 
add folklore value into copyright litigation because intellectual property is an area of law by pragmatism and an explicit balancing of multiple conflicting rights. ${ }^{61}$ Copyright regime has less to do with religion or morality than with the nature of individual authorship. In this matter, a system of legal protection for indigenous folklore has to recognize this fact to be effective. In the International level, the protection of cultural heritage (including folklore) is not only under intellectual property regime, but also outside intellectual property regime. In the United Nation (UN) Declaration of indigenous people, the protection outside intellectual property includes identification, documentation, preservation, or promotion of folklore. ${ }^{62}$ But it does not provide the right of indigenous people to control the uses of their heritage. The non-legally binding Declaration was adopted by the United Nation General Assembly on September 13, 2007.

The protection inside intellectual property right has been initiated since 1967. At Stockholm Revision Conference of the Berne Convention, most countries (developing and industrialized countries) strongly raised the issue of folklore. ${ }^{63} \mathrm{As}$ a result, Article 15 (4) the Berne Convention for the Protection for literary and Artistic Works (Berne Convention) regulates copyright of unpublished works by unknown authors. This Article does not mention the word "folklore", but "unpublished works where the identity of the author is unknown, every ground to presume that he is a national of a country of the Union". Taking into account that Folklore is usually unpublished and does have unidentifiable author/or group of authors, it also relates to a particular expression of a specific geographical area. However, this Article does not sufficiently take the particularities of folklore into account. ${ }^{64}$ The particularities of folklore usually involve communal rights; while the amendment

${ }^{61}$ Michael F. Brown, Who Owns Native Culture? (Harvard University Press 2003).[53].

${ }^{62}$ Indigenous Peoples "have the right to maintain, control, protect and develop their cultural heritage, traditional knowledge and traditional cultural expressions...including human and genetic resources... They also have the right to maintain, control, protect and develop their intellectual property over such cultural heritage, traditional knowledge, and traditional cultural expressions." (Article 31 UN Declaration on the Rights of Indigenous Peoples)

${ }^{63}$ Silke von Lewiski (n 58).[535].

${ }^{64}$ ibid.[356]. 
implies individual rights. ${ }^{65}$ Another issue to discuss is that until today there is no state notifying the existence of any competent body. ${ }^{66}$

In 1976, many developing countries incorporated in the UNESCO and WIPO tried new approach to include provisions of folklore in the Tunis Model Law on Copyright for Developing Countries. The aims of the inclusion of the provisions in the non-binding model law are to prevent any improper exploitation and to permit adequate protection of folklore. ${ }^{67}$ It also constitutes a potential for economic expansion and a cultural legacy intimately bound up with the individual character of each people. ${ }^{68}$ On these grounds, folklore deserves protection, and both economic and moral rights ${ }^{69}$ will be exercised by competent authority ${ }^{70}$ without limit of time. ${ }^{71}$ Furthermore, in section 1 (5bis) in this model provision, the fixation of folklore would not be required. This Article makes an exception of the principle of copyright for folklore. In copyright principle, a work can be protected only when it has been transferred into a "tangible medium". ${ }^{72}$ In other words, fixation of an idea is a must in copyright regime. In this matter, only the expression of the work can be protected under copyright regime. Indeed, the model provisions adapt folklore much better than the Berne Convention although they demonstrated some shortages, for example not stating the definition and collective nature of folklore in the model provisions. ${ }^{73}$

The willingness to protect folklore has been improved since 1982 when WIPOUNESCO adapted the Model Provisions for National Laws on the Protection of Expressions of Folklore against Illicit Exploitation and Other Prejudicial Actions. In the Model Provisions, legal protection for folklore under copyright laws and treaties

${ }^{65}$ Paul Kuruk, Protecting Folklore Under Modern Intellectual Property Regimes: A Reapraisal of the Tensions Between Individual and Communal Rihgts in Africa and the United States $<\mathrm{www}$. wcl.america.edu/Journal>.[45].

${ }^{66} \mathrm{ibid}$.

${ }^{67}$ Tunis Model Law on Copyright for Developing Countries, Adopted by the Committee of Governmental Experts of UNESCO and WIPO in Tunis, 23 Februray-2 March, 1976, Commentary by the Secretary of UNESCO and the International Bureau of WIPO. Para. 39.

${ }^{68}$ ibid.

69 ibid.

70 ibid. Section 6 (1).

71 ibid. Section 6 (2).

${ }^{72}$ Michael F. Brown (n 61).[59].

${ }^{73}$ Silke von Lewiski (n 58). Paul Kuruk (n 65).[236]. 
seems not suitable since it is not sufficient to control the commercial use of folklore and is not the proper laws to protect folklore. ${ }^{74}$ This is because the result of the expression of folklore is an impersonal, continuous, and slow process of creativity exercised in given community by consecutive imitation. ${ }^{75}$ However, works protected by copyright must bear decisive mark of originality. ${ }^{76}$ Besides, the time frame for protection of copyright regime is not suitable with the nature of folklore. ${ }^{77}$

Even though copyright law provides similar rights for folklore, it does not meet every criteria of copyright, such as: originality, material form, implies for individual rights, and time frame of protection. Originality refers to a work protected under copyright law and not a copy from another work. ${ }^{78}$ However, indigenous artists copy the works of their cultural heritage. With regard to material form, copyright regime only concerns with fixation or expressions of thought. Differently, in folklore, fixation is not a must which do not meet this criterion. Copyright regime implies individual rights, while folklore refers to communal rights. Different from the limited time of protection for works under copyright regime, the protection of folklore is unlimited, while there is time limit for copyright. The above reasoning leads to a conclusion that it is necessary to choose a special (sui generis) type of law for an adequate protection against unauthorized exploitation..$^{79}$ To distinguish the protection between folklore and ordinary copyright laws, the model provisions use the words expressions and productions instead of works. ${ }^{80}$ Section 2 of this model provisions define the meaning of expressions of folklore as productions consisting of characteristic elements of the traditional artistic heritage developed and maintained by a community or by individuals reflecting the traditional artistic expectations

${ }^{74}$ Model Provisions for National Laws on the Protection of Expression of Folklore Against Illicit Exploitation and Other Prejudicial Actions, UNESCO-WIPO, 1985, Introductory Observations (n 56).[Para. 10].

75 ibid.

76 ibid.

77 ibid.

78 Terri Janke, Our Culture: Our Future, Report on Australian Indigenous Cultural and Intellectual Property Rights (1998).[53].

79 ibid.[para.14].

${ }^{80}$ Paul Kuruk (n 65).[47]. 
of such community. Furthermore, this section also expresses the extension of the protection of folklore, such as whether it is expressed verbally ${ }^{81}$, musically ${ }^{82}$, by action ${ }^{83}$, or in tangible form. ${ }^{84}$ The model provisions seem to avoid the concept of ownership by using the term "competent authority" ${ }^{85}$ In this matter, if the protected folklore is to be used for profit outside the traditional context, prior approval is needed from this competent authority. ${ }^{86}$ There are also some exceptions to such rights of authorization. ${ }^{87}$ Furthermore, the Model provisions allow criminal penalties.

"The criminal penalties to be imposed for: failing to obtain the required written consent prior to use of protected folklore; failing to acknowledge the source of folklore; misrepresenting the origin of expressions of folklore; distorting works of folklore in any manner considered prejudicial to the honor, dignity, or cultural interests of the community from which it originates; objects made in violation of the Model Provisions and any profits made there from can be seized". 88

The Model Provisions have been conceived on the way towards international protection. Protection of folklore expression in foreign countries is based on reciprocity agreements among countries adopting the Model provisions, or based on other international agreements. ${ }^{89}$ Regrettably, although the Model Provisions contain useful features, to date, they have not been adopted by any country. ${ }^{90}$ As a result, the legal certainty of folklore in the international level, once again, fades away.

${ }^{81}$ Model Provisions for National Laws on the Protection of Expression of Folklore Against Illicit Exploitation and Other Prejudicial Actions, UNESCO-WIPO, 1985, Introductory Observations (n 56). section 2 (i).

82 ibid. section 2 (ii).

83 ibid. section 2 (iii).

84 ibid. section 2 (iv).; Paul Kuruk (n 65).

85 ibid.[48]. together with Model Provisions for National Laws on the Protection of Expression of Folklore Against Illicit Exploitation and Other Prejudicial Actions, UNESCO-WIPO, 1985, Introductory Observations (n 57).Section 9.

${ }^{86}$ Model Provisions for National Laws on the Protection of Expression of Folklore Against Illicit Exploitation and Other Prejudicial Actions, UNESCO-WIPO, 1985, Introductory Observations (n 57). Section 3 and 6.

87 ibid. Section 4.

${ }^{88}$ Paul Kuruk (n 65).[48] together with Model Provisions for National Laws on the Protection of Expression of Folklore Against Illicit Exploitation and Other Prejudicial Actions, UNESCO-WIPO, 1985, Introductory Observations (n 56). Section 6, 7, 8.

${ }^{89}$ Model Provisions for National Laws on the Protection of Expression of Folklore Against Illicit Exploitation and Other Prejudicial Actions, UNESCO-WIPO, 1985, Introductory Observations (n 56).[14].

90 Paul Kuruk (n 65).[49]. 
The plan to negotiate a treaty on the sui generis protection of folklore, organized by WIPO and UNESCO, was held in Phuket in 1997. The aim of this Diplomatic Conference is to 'complete the drafting of a new international agreement on the sui generis protection of folklore'. ${ }^{91}$ Four years later, in order to discuss genetic resources and traditional knowledge which also cover folklore, WIPO Intergovernmental Committee was establish. Even today the above mentioned international agreements have not been completed. In the first session of WIPO Intergovernmental Committee (ICG) on Intellectual Property and Genetic Resources, Traditional Knowledge and Folklore were held on May 2001; and the most recent session, the twenty-second, took place on July 9-13, 2012.92 The latest session focused on four keys articles; Article 1 on the subject matter of protection, Article 2 on beneficiaries; Article 3 on the scope of protection; and Article 5 on exceptions and limitations..$^{93}$ The discussion on the Articles presented below is based on the revision version on the 22nd session of the ICG meeting in July 12, 2012. ${ }^{94}$ At this revision version of draft Articles, there are still some points of disagreement or policy differences (using square brackets or through the use of alternatives). ${ }^{95}$

In the draft revision of Article 1, there are two objects matters: definition of traditional cultural expression (TCEs) and the criteria of eligibility. The definition of traditional cultural expressions is stated in Article 1 (1):

Any form of [artistic] expression, tangible and/or intangible or a combination thereof,

Alternative 1: in which traditional culture and [knowledge] are embodied.

Alternative 2: which are indicative of traditional culture and [knowledge].

\footnotetext{
91 World Intellectual Property, 'Document Wo/Ga/40/7' < www.wipo.int/edocs/mdocs/govbody/en/wo_ga.../wo_ga_40_7.doc>.[para.16].

92 Sessions held in May 2001, December 2001, June 2002, December 2002, July 2003, March 2004, November 2004, June 2005, April 2006, November-December 2006, July 2007, February 2008, October 2008, July 2009, December 2009, May 2010, July 2010, December 2010, February 2011, March 2011, May 2011, July 2011, February 2012, April 2012, July 2012. <http://www.wipo. int/meetings/en/topic.jsp?group_id=110\&items $=10>$

${ }_{93}$ Draft Article, Intergovernmental Committee on Intellectual Property and Genetic Resources, Traditional Knowledge and Folklore, 22 ${ }^{\text {nd }}$ Session, Genewa, 9-12 July, 2012 (doc:WIPO/GRT$\mathrm{KF} / \mathrm{IC} / 22 / 4)$.

94 World Intellectual Property (n 12). as revised by the Facilitator, July 12, 2012.

95 ibid. Comments on Article 1, point 2.
} 
[which pass from generation to generation and between generations], including but not limited to:

(a) phonetic or verbal expressions, [such as stories, epics, legends, poetry, riddles and other narratives; words, signs, names, and symbols];

(b) musical or sound expressions, [such as songs, rhythms, and instrumental music, the sounds which are the expression of rituals];

(c) expressions by action, [such as dances, plays, ceremonies, rituals, rituals in sacred places and peregrinations, traditional sports and games, puppet performances, and other performances, whether fixed or unfixed]; and

(d) tangible expressions, [such as material expressions] of art, [handicrafts, handmade carpets, architecture, and tangible spiritual forms, and sacred places];

(e) Adaptations of the expressions referred to in the above categories.

In this Article, ICG tries to draw the definition of traditional cultural expression more detail with some examples. This approach could better identify the areas of protection. Furthermore, the concept of passing the TCEs over generation to generation in the definition is still debatable. European Union (EU) refuses this concept, and prefers to put it into eligibility criteria, not in the definition matter. ${ }^{96}$ Next comment is about the adaptation of TCEs in point e of this Article. Since there is no explanation or example, the definition becomes broader; it is because TCEs evolve and develop over time. Article 1 (2) states:

Protection extends to traditional cultural expressions that are:

(a) [the result of the creative intellectual activity] of;

(b) [distinctive of the unique product of]/[associated with] the cultural and social identity of; [and/or]

(c) [held] maintained, used or developed as part of the cultural and social identity [or heritage] by

The beneficiaries as defined in Article 2

The terminology "creative intellectual activity" infers that not all TCEs can be categorized as intellectual activity, for example rituals. ${ }^{97}$ In this matter, it will be difficult to prove this criterion. Since there are still a lot of different opinions among delegations and experts about the eligibility criteria, until the last session, this subject can not be concluded. ${ }^{98}$

\footnotetext{
96 ibid. Point 3.

97 ibid. Point 5.

98 ibid.
} 
Article 1 (3) states that:

"The terminology used to describe the protected subject matter should/shall be determined in accordance with national law and where applicable, regional law".

The term "law" here could include regulation, case law, and legislation. The term "regional law" would refer to EU law. In Indonesian national law, the definition and the eligibility criteria are not as complete as this draft Articles. ${ }^{99}$ In this matter, if these draft Articles are included into International law with binding power for contracted states, it will be difficult for Indonesia to invoke these Articles to protect its TCEs (including folklore) in international level.

Article 2 is about the beneficiaries of protection. In the revised draft Article 2, it is stated that:

"Beneficiaries of protection are indigenous [peoples] or [local communities], [or as determined by national law or by treaty] [who hold maintain, use, or develop] the traditional the traditional cultural expression as defined in/ determined by Article 1".

In this revision draft Article, the term "indigenous people and the local communities" remain debatable. It is because these two terms can not appropriately define the subject of the protection. ${ }^{100}$ Again, national law has to determine the subject matter to protect its own TCEs.

Article 3 is about the scope of protection.

\section{Option 1}

The economic and moral interests of the beneficiaries of traditional cultural expressions, as defined in Articles 1 and 2, should/shall be safeguarded as appropriate and according to national law, in a reasonable and balanced manner.

Option 2

Adequate and effective legal, administrative or policy measures should be provided to:

(a) prevent the unauthorized disclosure, fixation or other exploitation of secret traditional cultural expressions;

(b) acknowledge the beneficiaries to be the source of the traditional cultural

${ }^{99}$ Paul Kuruk (n 65). chapter II in this contribution.

$100 \quad$ World Intellectual Property (n 12). as revised by the Facilitator, July 12, 2012, Comments on Article 2, point 1. 
expression, unless this turns out to be impossible;

(c) prevent use which distorts or mutilates a traditional cultural expression or that is otherwise offensive, derogatory or diminishes its cultural significance to the beneficiary;

(d) protect against any false or misleading uses of traditional cultural expressions, in relation to goods and services, that suggest endorsement by or linkage with the beneficiaries; and

(e) [there are two options for paragraph (e), which deals with commercial exploitation]:

Alternative 1: where appropriate, enable beneficiaries to authorize the commercial exploitation of traditional cultural expressions by others.

Alternative 2: ensure beneficiaries have exclusive and [inalienable] collective rights to authorize and prohibit the fallowing in relation to their traditional expressions:

(i) Fixation;

(ii) Reproduction;

(iii) public performance;

(iv) translation or adaptation;

(v) making available or communicating to the public;

(vi) distribution;

(vii) any use for commercial purposes, other than their traditional use; and

(viii) the acquisition or exercise of intellectual property rights.

In the Option 1 of this Article 3 has maximum flexibility. While the policy approach in Option 2 is more detail and prescriptive. In this matter the committee tries to accommodate both adequate and effective legal policy to safeguard the economic and moral interest of the beneficiaries.

Article 5 is about exception and limitation:

1. Measures of protection of traditional cultural expressions should/shall not restrict the creation, customary use, transmission, exchange and development of traditional cultural expressions by the beneficiaries, within and among communities, in the traditional and customary context [consistent with national laws of the member state which applicable].

2. Limitations and protection should/shall extend only to the utilizations of traditional cultural expressions taking place outside the membership of the beneficiary community or outside traditional cultural context.

3. Member States may adopt appropriate limitations or exceptions under national law, provided that the rule of traditional cultural expressions:

Alternative 1:

(a) acknowledges the beneficiaries, where possible;

(b) is not offensive or derogatory to the beneficiaries; and

(c) is compatible with fair practice. 
Alternative 2:

(a) is limited to certain special cases;

(b) does not conflict with the normal utilization of the traditional cultural expressions by the beneficiaries; and

(c) does not unreasonable prejudice the legitimate interest of the beneficiaries.

1. Regardless of whether such as acts are already permitted under Article 5 (3) or not, the fallowing should/shall be permitted [only with the free prior and inform consent of the beneficiaries];

(a) the use of traditional cultural expressions in archives, libraries, museums, or cultural institutions for non-commercial cultural heritage purposes, including for preservation, display, research, presentation and education;

(b) [the creation of the original work of authorship inspired by or borrowed from traditional cultural expressions].

2. [except for the secret of traditional cultural expressions against disclosure], to the extent that any act will be permitted under the national law for works protected by copyright or signs and symbols protected by trademark law, such acts shall/ should not be prohibited for the protection of traditional cultural expressions].

Based on this draft Article, the committee tries to give protection for originality of extension creation inspired by traditional cultural expression under copyright or trademark regime.

These Draft Articles have no power to impose international obligations to the contracting States, including Indonesia. However, these instruments could be the means for protecting indigenous culture and improving legal awareness on the importance of the protection. These international forums are the good start to obtain international recognition for the existence of indigenous culture. Furthermore, these forums might inspire Indonesian Government to consider special legislation or sui generis solution in regulating indigenous culture in order to avoid uncertainty in the implementation of Indonesian Copyright Law.

Still in the framework of international protection of Indigenous culture, on August 8-10, 2012, first WIPO Interregional Meeting on South-South Cooperation on Intellectual Property (IP) Governance, Genetic Resources, Traditional Knowledge and Folklore (GRTKF), and Copyright and Related Rights will be held on Brazil. The Meeting will address national experiences in the protection of traditional knowledge, traditional cultural expressions and genetic resources, and will also discuss how to facilitate international cooperation, in particular South- 
South cooperation, in using the IP system for the protection of GRTKF. ${ }^{101}$

\section{Author's Rights and Copyright for Traditional Batik}

While the concept of folklore protection in international level is developed into the negotiation of sui generis for folklore, ${ }^{102}$ in Indonesian law, as already discussed in chapter II, folklore is protected under copyright regime. Even though folklore has special treatment (such as time protection duration, ${ }^{103}$ and the authorship of folklore ${ }^{104}$ ), the measurement of folklore falls into the concepts of copyright regime as long as it is regulated under Indonesian copyright $\mathrm{Law}^{105}$ and there is no implementing regulation. ${ }^{106}$ Consequently, copyright protection for Batik as folklore may be hampered by authorship and originality. In copyright regime, the author is related to the originality requirement. ${ }^{107}$ Behind an existing work, there must be an identifiable author (authors) who creates the work with his/her/their skill to show its originality. Therefore, authorship and originality are inseparable aspects in the protection under copyright regime.

Based on the concept of authorship in Indonesian Copyright Law, ${ }^{108}$ work is a creation of person (persons) from whom an artistic idea comes, based on their intellectual ability, imagination, dexterity, skill or expertise manifested in a distinctive form. Artistic work is a result of creativity by an author. In this matter, Indonesian copyright law grants independent personal rights for an author as the

${ }^{101}$ WIPO Interregional Meeting on South-South Cooperation on Intellectual Property (IP) Governance, 'Genetic Resources, Traditional Knowledge and Folklore (GRTKF); and Copyright and Related Rights, WIPO News and Events' <http://www.wipo.int/meetings/en/2012/wipo_ip_ grtkf_bra_12/index.html>.

${ }^{102}$ See Chapter III this contribution.

${ }^{103}$ Article 60 (1) Law Number 28 Year 2014 Concerning Copyright (The Republic of Indonesia State Gazette Year 2014 Number 266, Annotation 5599) (n 1). and the Chapter II of this contribution

${ }^{104}$ ibid. Article 38 (1)

${ }^{105}$ ibid. Article 38

106 ibid. Article 10 (4)

${ }^{107}$ Hayyan ul Haq, Requestioning the Existence of the Indonesia Copyright Regime in Protecting Cultural Property., Molengrafica, Series: Intellectual Property Law Articles on Crossing Borders between Traditional and Actual (2004).[229].

${ }^{108}$ Article 4 Law Number 28 Year 2014 Concerning Copyright (The Republic of Indonesia State Gazette Year 2014 Number 266, Annotation 5599) (n 1).also in Chapter II of this contribution. 
owner of his/her/their works, both moral rights ${ }^{109}$ and certain economic rights to exploit their creations. That is why identifiable author (authors) is an unavoidable aspect in copyright regime. Identifiable author concept is characteristic of cultural ambience in which each person is clearly differentiated being who is conscious of their individuality. ${ }^{110}$

However, it is difficult to acknowledge who is the author of traditional Batik in Indonesia. To protect Batik as folklore, Indonesian copyright Law has to face two notions: individualism and communalism. Communitarians determine the social dimension of individuals. ${ }^{111}$ Communalism concerns on the attachment of rights and duties of individuals towards other individuals and their society. ${ }^{112}$ Most Batik artists believe that their works are from their community and for their community. Communalism of the creation of traditional Batik is a commodity or a form of property and a manifestation of an ancient and continuous relationship between people and their territory. Consequently, it is often the case that no individual can be solely identified as an author of traditional Batik manifested as folklore.

The other problem to concern is defining ownership. There is the related requirement that an author of the work be identified to whose ownership may be attributed. As already discussed in Chapter II, in Indonesian copyright Law, author has moral right. In this matter, as the first owner, ${ }^{113}$ author's moral right can reach into the exploitation rights granted to third parties by way of assignment or license and his/her/their heirs (which basically covers the rights of publication, ${ }^{114}$ paternity, ${ }^{115}$

\footnotetext{
${ }^{109}$ ibid.

${ }^{110}$ Lypszyc Delia, Villalba, Alberto, Preserving and Accessing Our Cultural Heritage: Argentina's Experience through the Domaine Public Payant, Copyright and the Cultural Heritage: Preservation and Access to Works in a Digital World, Ed. Derclaye, Estelle, 2011) (Edward Elgar). [179].

${ }^{111}$ Hayyan ul Haq (n 107). Molengrafica (n 107).[226].

112 A.S. Akermark, Justification of Minority Protection in International Law (Kluwer Law International). [43].

${ }^{113}$ Andreas Rahmatian (n 29).[52].

${ }^{114}$ The rights of publication: allow creatorto decide whether his work will be made public, see Hayyan ul Haq (n 107). Molengrafica (n 107).[238].

115 The paternity right ensures that the author is credited with the creation of his/her/they of with the creation of his published works, see Hayyan ul Haq (n 107). Molengrafica (n 107).
} 
and integrity $\left.{ }^{116}\right)$. The copyright regime believes that economic benefit is the primary motivation for creativity which leads to economic exploitation. ${ }^{117}$ This individual ownership principle could be inappropriate for indigenous cultural folklore which chooses indigenous concept of communal ownership. ${ }^{118}$

In the communal ownership, some questions might appear:

1. If a community holds rights in traditional works, what does that mean for any party that wants to license the work for reproduction? ${ }^{119}$

2. Can a company enter into licensing arrangements with an artist without formerly communicating with the community who holds the right of traditional works? 120

3. How do we define the artist's community? Does it consist only of those who reside around a specific area, or include all people in an island? ${ }^{121}$

Indonesian Copyright Law tries to provide the answers for these questions. According to Article 38 Law No. 28/2014, ${ }^{122}$ as the right holder, the State is obliged to manage and control indigenous cultural products. It includes the right to give permission to non-nationals who wish to publish or reproduce any of it. As already discussed in Chapter II, many traditional Batik motives are registered under copyright regime by Indonesian local Governments at DGIPR. ${ }^{123}$ Some local governments register their Batik motives and claim them as their local properties. Local government of Pekalongan, for instance, is a copyright holder of some traditional Pekalongan Batik motives. In this matter, Indonesia Local Government of Pekalongan is assumed as the community who owns the rights of the traditional

116 The right of integrity protects the work from distortion, alteration, or wrong representation, see Hayyan ul Haq (n 107). Molengrafica (n 107).

${ }^{117}$ Joseph Githaiga, 'Intellectual Property Law and the Protection of Indigenous Folklore and Knowledge' (1998) 5 Murdoch University Electronic Journal of Law.

118 ibid.

${ }^{119}$ Series of questions launched by Justice von Doussa in the case of copyright-infringement brought by Aboriginal artists against Australian manufacturers and retailers, Bulun Bulun and Milpururru v. R \& T Textiles Pty Ltd. See Michael F. Brown (n 61).[49-50].

\footnotetext{
${ }^{120}$ ibid.

${ }^{121}$ ibid.

${ }^{122}$ See Chapter II of this contribution.

${ }^{123}$ See Chapter II of this contribution.
} 
Batik. Pursuant to this Article, if a foreign company wants to license the works for production, it required permission from the local Government. In this matter, there are still some critical problems. How if a local company wants to get a license of the work? For example, a local company owned by an Indonesian citizen from Bandung ${ }^{124}$ wants to produce traditional Batik from Pekalongan in a huge scale of production, does the law allow that? Who owns traditional Batik from Pekalongan? In this matter, who is the member of the community of indigenous people? Is it Pekalongan Government? People who lives and stay in Pekalongan? Descendants of people from Pekalongan? Or every Indonesian citizen? There is no clarity whether to include folklore as the property of Indonesia (as a whole) or as the property of local communities in Indonesia. Referring to Article 38 (3) Law No. 28/2014 it is indicated that national folklores are 'owned' by every Indonesian citizen. Furthermore, if the company gets permission from Indonesian Government, how is the procedure to transfer or to hand in all the remuneration or economical advantages for the community? It remains ambiguous on how to exercise the copyright, how to distribute the rewards, and whether there is any sanction and remedy for any infringement of the copyright from other communities.

The non-national license to make use of Indonesian folklore could stimulate cultural exchange and accelerate the development of regional identity. ${ }^{125}$ It will also make folklore widely known and will improve the economic value of folklore. ${ }^{126}$ If the policy to protect folklore is too strict, it will increase monopolization in utilizing folklore. ${ }^{127}$ Furthermore, if each region does the same thing, it will create a barrier for cultural exchange. Once Batik motive was created, it will be reproduced, and used for many products (shoes, wall papers, carpets, bags, etc). It means that one creation of batik motive gives benefits for many people. Since the license to use the cultural heritage only remains for non-nationals, it seems that traditional Batik

\footnotetext{
${ }^{124}$ Name of a city in West Java.

125 European Community, 'Expressions of Folklore, Intergovernmental Committee on Intellectual Property and GRTKF, 3rd Session' (16 May 2002).

${ }^{126} \mathrm{ibid}$.

${ }^{127}$ Hayyan ul Haq (n 107).[237].
} 
can be exploited freely within Indonesian territory and by Indonesian citizens. As already discussed in Chapter I, there are thousands Batik motives in Indonesia. Batik motive is not static, it is dynamic. There are many creations inspired by previous motives. Some Batik motives are recognized as folklore and already registered by Local Governments of Indonesia.

Pursuant to Article 12 (i) Law No. 19/2002, Batik is one of the objects protected under copyright law. It means Batik artists can rely on copyright law to protect their works as long as certain criteria are met, such as: originality, conclude into material form, and identifiable author. Based on this Article, a new Batik motive could be protected under copyright law. The author (authors) of the Batik motive can be identified as individual person, and thus personal rights of the author (authors). In other condition, some Batik motives identified as folklore fall under Article 38 Law No. 28/2014. In this matter, there is a new Batik motive based upon or derived from a traditional, pre-existing theme that could be protected as folklore. The owner of this kind of Batik motive is indigenous people, known as communal rights.

Even though the object is Batik motive, it seems that there are two different kinds of ownership under Indonesian Copyright Law. There are Batik motives owned by individual person, and the others owned by communal or indigenous people. As a result, there are different periods of time when the copyright works remain protected as folklore or not. According to Article 58 (1) Law No. 28/2014, the copyright validity of Batik arts is for the whole life of the author and 70 years after his death. While for traditional Batik as folklore under Article 60 (1) Law No. $28 / 2014$, the validity of the protection has no limit of time.

There is no measurement on how to determine which Batik motives can be categorized as folklore. It is difficult to decide which Batik motive could be folklore, which one is not. Since there is no provision declaring about the definition of folklore, it remains an unsolved problem. It is undeniable that the copyright regime as a part of intellectual property rights stimulates developing creativity and 
productivity. ${ }^{128}$ It is worrisome that the law uncertainty due to the protection for Batik arts will inhibit the creativity of Batik artists.

\section{Conclusion}

Based on the definitions of folklore, there are some basic elements to categorize the subject of folklore, they are: creations of traditional artistic works, in certain community or group of people or region, inherited from generation to generation, constitute the cultural heritage of the community or the group of people or the region. Batik has fulfilled these basic elements of folklore because of the fallowing reasons: Batik is pattern drawn on silk, cotton, or any kind of media. Traditional batik motives are intertwined with the cultural identity of Indonesian people, through the symbolic meanings of its colors and designs, expressing their creativity and spirituality. The knowledge for the traditional motives and the making process are often passed within families across generations. UNESCO acknowledges Batik as Indonesian cultural heritage. The acknowledgement by International Organization proves that the effort of Indonesian Government to protect its national heritage has moved one step forward. Not only seeking the acknowledgment in International level, Indonesian Government also protect Batik under national law. Traditional Batik in Indonesia is protected under copyright law. Since traditional Batik meet the condition of the nature of folklore, Indonesian Government decide to register traditional Batik as owned by local Government. Pursuant to Article 38 Law no. $28 / 2014$, as the right holder, the State is obliged to manage and control indigenous cultural products. It includes to be the one who publish or reproduce any piece of it. There are some critical problems to protect folklore. Since Government Regulation mentioned in the Article has not been compiled, there is no legal certainty to protect folklore in Indonesia. In International level, the protection of folklore as a part of indigenous culture is even more complex. The problem occurred when there is a misunderstanding between the concept of indigenous culture and copyright.

${ }^{128}$ ibid. [218]. 
Copyright deals with individualistic, exclusive, and materialistic values, while indigenous culture deals with communalism and spiritualism. These differences lead to the idea to make special category (sui generis) for indigenous culture. Even though there are a number of forums and conferences in International level, until today, there is still no exact model provision to formulate the protection of folklore.

Batik in Indonesia is protected under copyright law. Under copyright regime, there is no clarity whether to include folklore as the property of Indonesia (as a whole) or as the property of local communities in Indonesia. Referring to Article 38 (1) Law No. 28/2014, it is indicated that national folklores are owned by the state. However, some local governments register their Batik motives and claim them as their local properties. Local government of Pekalongan, for instance, is a copyright holder of traditional Pekalongan Batik motives. In this case, folklore is the property of local community, and only the members of the community have the copyright of it. It remains ambiguous on how to exercise the copyright, how to distribute the rewards, and whether there is a sanction and remedy in case of any infringement from other communities.

Another critical problem is the protection of Batik which is not categorized as folklore. As long as the condition of copyright are met, Batik arts can be protected under Indonesian Copyright Law. In this matter, it has private ownership with personal rights embedded on it, identified author, and duration of protection. There are many traditional Batik motives known as folklore. There is a different treatment with this kind of Batik. Since the implementation of the regulation as mentioned in Article 10 (4) Law No. 19/2002 does not exist, it is difficult to categorize an artistic work like Batik, as folklore or not.

\section{Bibliography}

A.S. Akermark, Justification of Minority Protection in International Law (Kluwer Law International).

Alan Dundes, Analytic Essays in Folklore (Mouton Publishers 1979).

Andreas Rahmatian, Copyright and Creativity the Making of Property Rights in 
Creative Works (Edward Elgar 2011).

Ansori Sinungan, 'Intellectual Property, TRIPs and Preserving Cultural Heritage and the Environment: Indonesian Experience'<www.unescap.org>.

Barley Tasa Nugraha, 'Indonesia and Malaysia Battle Over Batik' (2009) <www. thejakartaglobe.com>.

Berliana N. Rohima, 'Parang Rusak, One of Batik Motif' (2012) < lianrohima. wordpress.com>.

Bisnis UKM, 'Batik Semarang 16 Kini Sukses Menembus Batas (2012)' <https:// bisnisukm.com/batik-semarang-16-kini-sukses-menembus-batas.html>.

Dan Ben-Amos, 'Toward a Definition of Folklore' (2006) <www.jstore.org/ journals>.

Dindagkop Pekalongan, 'Motif Batik Terdaftar Di Ditjen HKI' < perindagkop. pekalongan kota.go.id>.

European Community, 'Expressions of Folklore, Intergovernmental Committee on Intellectual Property and GRTKF, 3rd Session' (16 May 2002).

Hayyan ul Haq, Requestioning the Existence of the Indonesia Copyright Regime in Protecting Cultural Property.

Indonesian Batiks, <www.indobatiks.com>.

Intergovernmental Committee on Intellectual Property and Genetic Resources Traditional Knowledge and Folklore, 'Traditional Knowledge-Operational Terms and Definitions' (Third Session, Geneva, 2002) <www.wipo.int>.

Joseph Githaiga, 'Intellectual Property Law and the Protection of Indigenous Folklore and Knowledge' (1998) 5 Murdoch University Electronic Journal of Law.

Law Number 28 Year 2014 Concerning Copyright (The Republic of Indonesia State Gazette Year 2014 Number 266, Annotation 5599).

Lypszyc Delia, Villalba, Alberto, Preserving and Accessing Our Cultural Heritage: Argentina's Experience through the Domaine Public Payant, Copyright and the Cultural Heritage: Preservation and Access to Works in a Digital World, Ed. Derclaye, Estelle, 2011) (Edward Elgar).

Melchers, Dorothé, International and Comparative Copyright Law: Introduction to 
Copyright (Radboud Universiteit 2011).

Michael F. Brown, Who Owns Native Culture? (Harvard University Press 2003).

Michael F. Brown Kristen Carpenter, 'In Defense of Property' [2010] Journal Cultural Property.

Molengrafica, Series: Intellectual Property Law Articles on Crossing Borders between Traditional and Actual (2004).

Paul Kuruk, Protecting Folklore Under Modern Intellectual Property Regimes: A Reapraisal of the Tensions Between Individual and Communal Rihgts in Africa and the United States <www.wcl.america.edu/Journal $>$.

Peter Gelling, 'Score One for Indonesia in the War Over Batik' (2009) <www. nytimes.com>.

Ruth Towse, Creativity, Incentive and Reward: An Economic Analysis of Copyright and Culture in the Information Age (Edward Elgar 2001).

Silke von Lewiski, International Copyright Law and Policy (Oxford 2008).

Suhikmah, Upaya Pemerintah Daerah Provinsi Jambi Dalam Rangka Perlindungan Hukum Terhadap Ciptaan Motif Batik Yang Belum Terdaftar (Universitas Diponegoro 2008).

Terri Janke, Our Culture: Our Future, Report on Australian Indigenous Cultural and Intellectual Property Rights (1998).

The General Conference of UNESCO, 'Convention for the Safeguarding of the Intangible Cultural Heritage’ (2003).

Tunis Model Law on Copyright for Developing Countries, Adopted by the Committee of Governmental Experts of UNESCO and WIPO in Tunis, 23 Februray-2 March, 1976, Commentary by the Secretary of UNESCO and the International Bureau of WIPO.

UNESCO, 'Indonesian Batik' (2009) <www.unesco.org>.

University of Northern Colorado, 'History of Indonesian Batik' <www.arts.unco.edu $>$.

WIPO Interregional Meeting on South-South Cooperation on Intellectual Property (IP) Governance, 'Genetic Resources, Traditional Knowledge and Folklore (GRTKF); and Copyright and Related Rights, WIPO News and Events' $<$ http://www.wipo.int/meetings/en/2012/wipo_ip_grtkf_bra_12/index.html >. 
World Intellectual Property, 'Document Wo/Ga/40/7' <www.wipo.int/edocs/mdocs/ govbody/en/wo_ga.../wo_ga_40_7.doc>.

- 'The Protection of Traditional Knowledge: Draft Articles'<www.wipo.int>. Model Provisions for National Laws on the Protection of Expression of Folklore Against Illicit Exploitation and Other Prejudicial Actions, UNESCO-WIPO, 1985, Introductory Observations.

HOW TO CITE: Ria Setyawati, Mas Rahmah, Rahmi Jened, Nurul Barizah dan Agung Sujatmiko, 'The Tensions On The Protection Of LocalTraditional Indonesian Batik' (2021) 36 Yuridika. 